\title{
A Monthly Water-Balance Model Driven By a Graphical User Interface
}

Open-File Report 2007-1088 



\section{A Monthly Water-Balance Model Driven By a Graphical User Interface}

By Gregory J. McCabe and Steven L. Markstrom

Open-File Report 2007-1088 


\section{U.S. Department of the Interior DIRK KEMPTHORNE, Secretary}

\section{U.S. Geological Survey \\ Mark D. Myers, Director}

\section{U.S. Geological Survey, Reston, Virginia: 2007}

For product and ordering information:

World Wide Web: http://www.usgs.gov/pubprod

Telephone: 1-888-ASK-USGS

For more information on the USGS--the Federal source for science about the Earth, its natural and living resources, natural hazards, and the environment:

World Wide Web: http://www.usgs.gov

Telephone: 1-888-ASK-USGS

Any use of trade, product, or firm names is for descriptive purposes only and does not imply endorsement by the U.S. Government.

Although this report is in the public domain, permission must be secured from the individual copyright owners to reproduce any copyrighted materials contained within this report.

Suggested citation:

McCabe, G.J., and Markstrom, S.L., 2007, A monthly water-balance model driven by a graphical user interface: U.S. Geological Survey Open-File report 2007-1088, 6 p. 


\section{Contents}

Abstract
Introduction
The Water-Balance Model
Snow Accumulation
Direct Runoff
Snow Melt
Running the Water-Balance Program
Input Parameters
Duta Files
References Cited

\section{Figures}

1. Diagram of the water-balance model ..........................................................................

2. Screen image of the water-balance model graphical user interface .................................

3. Screen image of example output from the water-balance model.......................................

4. Screen image of example time series plotted by the water-balance model......................5

\section{Conversion Factors}

Inches (in) are converted to millimeters $(\mathrm{mm})$ by multiplying by 25.4 .

Millimeters (mm) are converted to inches (in) by dividing by 25.4 .

Temperature in degrees Celsius $\left({ }^{\circ} \mathrm{C}\right)$ may be converted to degrees Fahrenheit $\left({ }^{\circ} \mathrm{F}\right)$ as follows:

$$
{ }^{\circ} \mathrm{F}=\left(1.8 x^{\circ} \mathrm{C}\right)+32
$$

Temperature in degrees Fahrenheit $\left({ }^{\circ} \mathrm{F}\right)$ may be converted to degrees Celsius $\left({ }^{\circ} \mathrm{C}\right)$ as follows:

$$
{ }^{\circ} \mathrm{C}=\left({ }^{\circ} \mathrm{F}-32\right) / 1.8
$$





\title{
A Monthly Water-Balance Model Driven By A Graphical User Interface
}

\author{
By Gregory J. McCabe and Steven L. Markstrom
}

\begin{abstract}
This report describes a monthly water-balance model driven by a graphical user interface, referred to as the Thornthwaite monthly water-balance program. Computations of monthly water-balance components of the hydrologic cycle are made for a specified location. The program can be used as a research tool, an assessment tool, and a tool for classroom instruction.
\end{abstract}

\section{Introduction}

Monthly water-balance models have been used as a means to examine the various components of the hydrologic cycle (for example, precipitation, evapotranspiration, and runoff). Such models have been used to estimate the global water balance (Mather, 1969; Legates and Mather, 1992; Legates and McCabe, 2005); to develop climate classifications (Thornthwaite, 1948); to estimate soil-moisture storage (Alley, 1984; Mintz and Serafini, 1992), runoff (Alley, 1984, 1985; Yates, 1996; Wolock and McCabe, 1999), and irrigation demand (McCabe and Wolock, 1992); and to evaluate the hydrologic effects of climate change (McCabe and Ayers, 1989; Yates, 1996; Strzepek and Yates, 1997; Wolock and McCabe, 1999).

This report provides a description of a monthly water-balance model that is driven by a graphical user interface (GUI) developed by the U.S. Geological Survey. The GUI permits the user to easily modify water-balance parameters and provide useful estimates of water-balance components for a specified location. The model, referred to as the Thornthwaite water-balance program, can be used as a research tool, an assessment tool, and as a tool for classroom instruction. The program can be downloaded from the internet at $h t t p: / / w a t e r$. usgs.gov/lookup/get?crresearch/mms/thorn and can run on any platform.

\section{The Water-Balance Model}

The water-balance model (fig. 1) analyses the allocation of water among various components of the hydrologic system using a monthly accounting procedure based on the methodology originally presented by Thornthwaite (Thornthwaite, 1948; Mather, 1978, 1979; McCabe and Wolock, 1999; Wolock and McCabe, 1999). Inputs to the model are mean monthly temperature ( $T$, in degrees Celsius), monthly total precipitation ( $P$, in millimeters), and the latitude (in decimal degrees) of the location of interest. The latitude of the location is used for the computation of day length, which is needed for the computation of potential evapotranspiration (PET). The model is referred to as the Thornthwaite model. A discussion of the individual components of the water balance follows.

\section{Snow Accumulation}

The first computation of the water-balance model is the estimation of the amount of monthly precipitation $(P)$ that is rain $\left(P_{\text {rain }}\right)$ or snow $\left(P_{\text {snow }}\right)$, in millimeters. When mean monthly temperature $(T)$ is below a specified threshold $\left(T_{\text {snow }}\right)$, all precipitation is considered to be snow. If temperature is greater than an additional threshold $\left(T_{\text {rain }}\right)$, then all precipitation is considered to be rain. Within the range defined by $T_{\text {snow }}$ and $T_{\text {rain }}$, the amount of precipitation that is snow decreases linearly from 100 percent to 0 percent of total precipitation. This relation is expressed as:

$$
P_{\text {snow }}=P \times\left[\frac{T_{\text {rain }}-T}{T_{\text {rain }}-T_{\text {snow }}}\right] .
$$

$P_{\text {rain }}$ then is computed as:

$$
P_{\text {rain }}=P-P_{\text {snow }} \text {. }
$$

Based on an analysis of water-balance results for a number of sites, a useful value for $T_{\text {rain }}$ is $3.3^{\circ} \mathrm{C}$ (McCabe and Wolock, 1999). Useful values for $T_{\text {snow }}$ appear to vary by elevation. For elevations below $1,000 \mathrm{~m}, T_{\text {snow }}=-10^{\circ} \mathrm{C}$ seems to work best, and for locations above $1,000 \mathrm{~m} T_{\text {snow }}=-1^{\circ} \mathrm{C}$ is more appropriate. (These values were determined from previous model calibrations during testing and evaluation for streamflow-gage sites in the conterminous United States. (David Wolock, U.S. Geological Survey, Lawrence, Kans., personal commun).)

$P_{\text {snow }}$ accumulates as snow storage (snostor). 


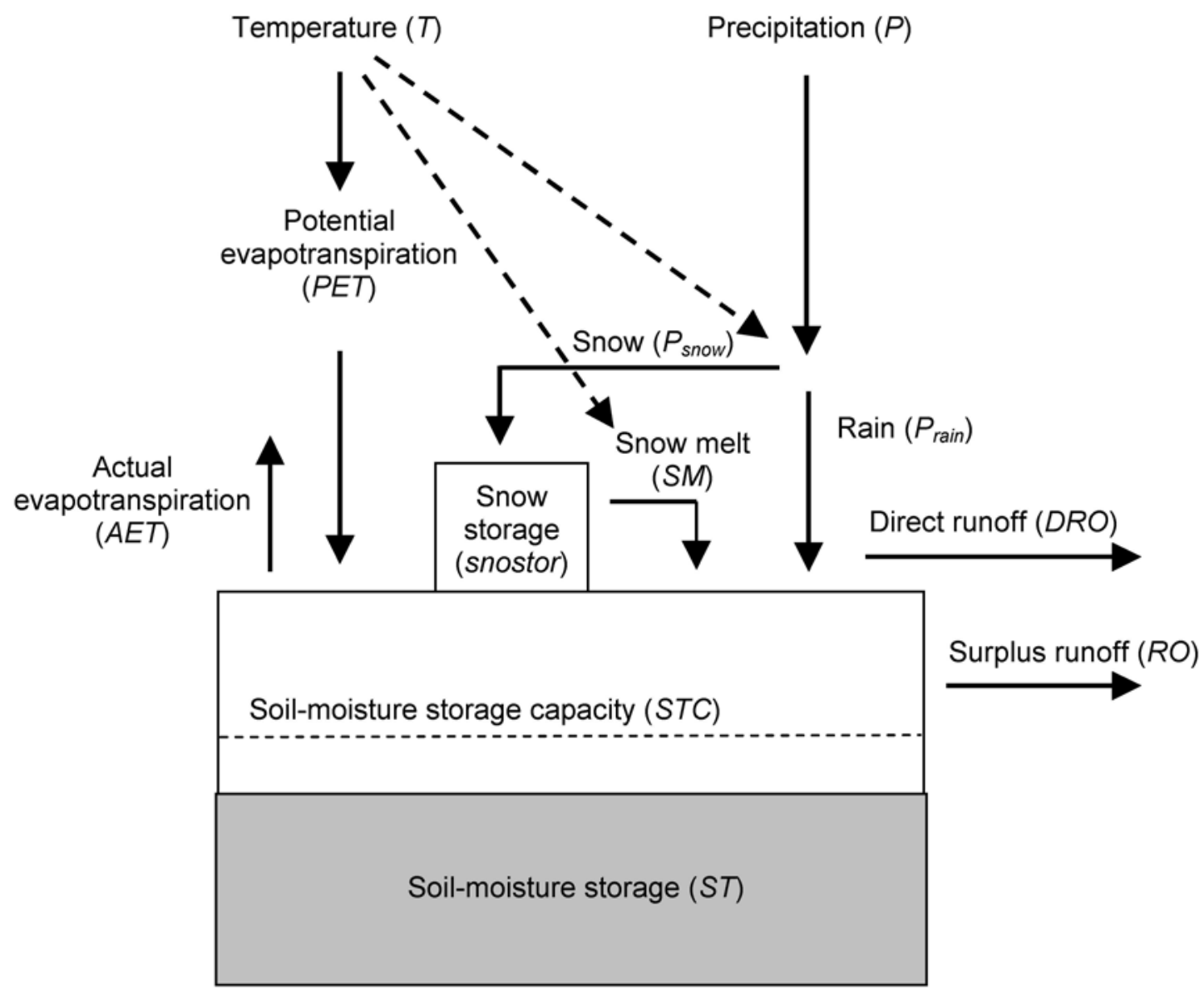

Figure 1. Diagram of the water-balance model.

\section{Direct Runoff}

Direct runoff $(D R O)$ is runoff, in millimeters, from impervious surfaces or runoff resulting from infiltration-excess overflow.

The fraction (drofrac) of $P_{\text {rain }}$ that becomes $D R O$ is specified; based on previous water-balance analyses, 5 percent is a typical value to use (Wolock and McCabe, 1999). The expression for $D R O$ is:

$$
D R O=P_{\text {rain }} \times \text { drofrac }
$$

Direct runoff $(D R O)$ is subtracted from $P_{\text {rain }}$ to compute the amount of remaining precipitation $\left(P_{\text {remain }}\right)$ :

$$
P_{\text {remain }}=\mathrm{P}_{\text {rain }}-D R O \text {. }
$$

\section{Snow Melt}

The fraction of snostor that melts in a month (snow melt fraction, $S M F$ ) is computed from mean monthly temperature
(T) and a maximum melt rate (meltmax); meltmax is often set to 0.5 (McCabe and Wolock, 1999; Wolock and McCabe, 1999). The fraction of snow storage that melts in a month is computed as:

$$
S M F=\frac{\mathrm{T}-\mathrm{T}_{\text {snow }}}{\mathrm{T}_{\text {rain }}-\mathrm{T}_{\text {snow }}} \times \text { meltmax }
$$

If the computed $S M F$ is greater than meltmax, then $S M F$ is set to meltmax. The amount of snow that is melted in a month $(S M)$, in millimeters of snow water equivalent, is computed as:

$$
S M=\text { snostor } \times S M F .
$$

$S M$ is added to $P_{\text {remain }}$ to compute the total liquid water input $\left(P_{\text {total }}\right)$ to the soil.

\section{Evapotranspiration and Soil-Moisture Storage}

Actual evapotranspiration (AET) is derived from potential evapotranspiration $(P E T), P_{\text {total }}$, soil-moisture storage $(S T)$, 
and soil-moisture storage withdrawal (STW). Monthly PET is estimated from mean monthly temperature $(T)$ and is defined as the water loss from a large, homogeneous, vegetation-covered area that never lacks water (Thornthwaite, 1948; Mather, 1978). Thus, $P E T$ represents the climatic demand for water relative to the available energy. In this water balance, $P E T$ is calculated by using the Hamon equation (Hamon, 1961):

$$
P E T_{\text {Hamon }}=13.97 \times d \times D^{2} \times W_{t},
$$

where $P E T_{\text {Hamon }}$ is $P E T$ in millimeters per month, $d$ is the number of days in a month, $D$ is the mean monthly hours of daylight in units of $12 \mathrm{hrs}$, and $W_{t}$ is a saturated water vapor density term, in grams per cubic meter, calculated by:

$$
W_{t}=\frac{4.95 \times \mathrm{e}^{0.062 \times T}}{100}
$$

where $T$ is the mean monthly temperature in degrees Celsius (Hamon, 1961).

When $P_{\text {total }}$ for a month is less then PET, then AET is equal to $P_{\text {total }}$ plus the amount of soil moisture that can be withdrawn from storage in the soil. Soil-moisture storage withdrawal linearly decreases with decreasing $S T$ such that as the soil becomes drier, water becomes more difficult to remove from the soil and less is available for AET.

$S T W$ is computed as follows:

$$
S T W=S T_{i-1}-\left[a b s\left(\mathrm{P}_{\text {total }}-\mathrm{PET}\right) \times\left(\frac{S T_{i-1}}{S T C}\right)\right],
$$

where $S T_{i-1}$ is the soil-moisture storage for the previous month and STC is the soil-moisture storage capacity. An STC of 150 mm works for most locations (McCabe and Wolock, 1999; Wolock and McCabe, 1999).

If the sum of $P_{\text {total }}$ and $S T W$ is less than $P E T$, then a water deficit is calculated as PET-AET. If $P_{\text {total }}$ exceeds PET, then $A E T$ is equal to $P E T$ and the water in excess of PET replenishes $S T$. When $S T$ is greater than $S T C$, the excess water becomes surplus $(S)$ and is eventually available for runoff.

\section{Runoff Generation}

Runoff $(R O)$ is generated from the surplus, $S$, at a specified rate (rfactor). An rfactor value of 0.5 is commonly used (Wolock and McCabe, 1999). The rfactor parameter determines the fraction of surplus that becomes runoff in a month. The remaining surplus is carried over to the following month to compute total $S$ for that month. Direct runoff (DRO), in millimeters, is added directly to the runoff generated from surplus $(R O)$ to compute total monthly runoff $\left(R O_{\text {total }}\right)$, in millimeters.

\section{Running the Water-Balance Program}

The window for the Thornthwaite monthly water-balance program will behave like any other window on the desktop. Resize, iconify, or close it like any other application by dragging the borders and clicking on the window controllers in the upper corners of the frame. Figure 2 is a screen image of the program's graphical user interface.

\section{Input Parameters}

The water-balance model has seven input parameters (runoff factor, direct runoff factor, soil-moisture storage capacity, latitude of location, rain temperature threshold, snow temperature threshold, and maximum snow-melt rate of the snow storage) that are modified through the graphical user interface (fig. 2). The range and default values for these parameters are set by the model. These values are changed by clicking on the corresponding slider bar and dragging the value. The system will not allow invalid values to be entered.

\section{Data Files}

The model requires a simple input data file. To select the input file, click on the button corresponding to the file ("Input file") and a file browser will appear. The input file must be a file on the user's local file system that contains monthly waterbalance input data. A sample data file (input.file) is provided with the model and is located in the USGS_Thornthwaite installation folder. The data file must be organized into four columns with one or more space characters between the columns. The first column is the year, the second is the numeric month of the year, the third is mean monthly temperature in degrees Celsius, and the last is monthly total precipitation in millimeters.

When the model runs, tabular output is written to a popup window (fig. 3). The columns of the output are date, PET, $P$, $P-P E T$, soil-moisture storage, AET, PET-AET (also known as moisture deficit), snow storage, surplus, and $R O_{\text {total }}$ The contents of this window can be saved to a file by clicking on the Save button at the bottom of the window and specifying the name (and directory) of an output file in the file browser.

At the bottom of the main program window (fig. 2), the user can select the specific variables to be plotted by clicking on the corresponding circle. After the model runs, a window will open with the plotted time series (fig. 4). The model can be run any number of times, each time selecting a different set of variables to plot. 


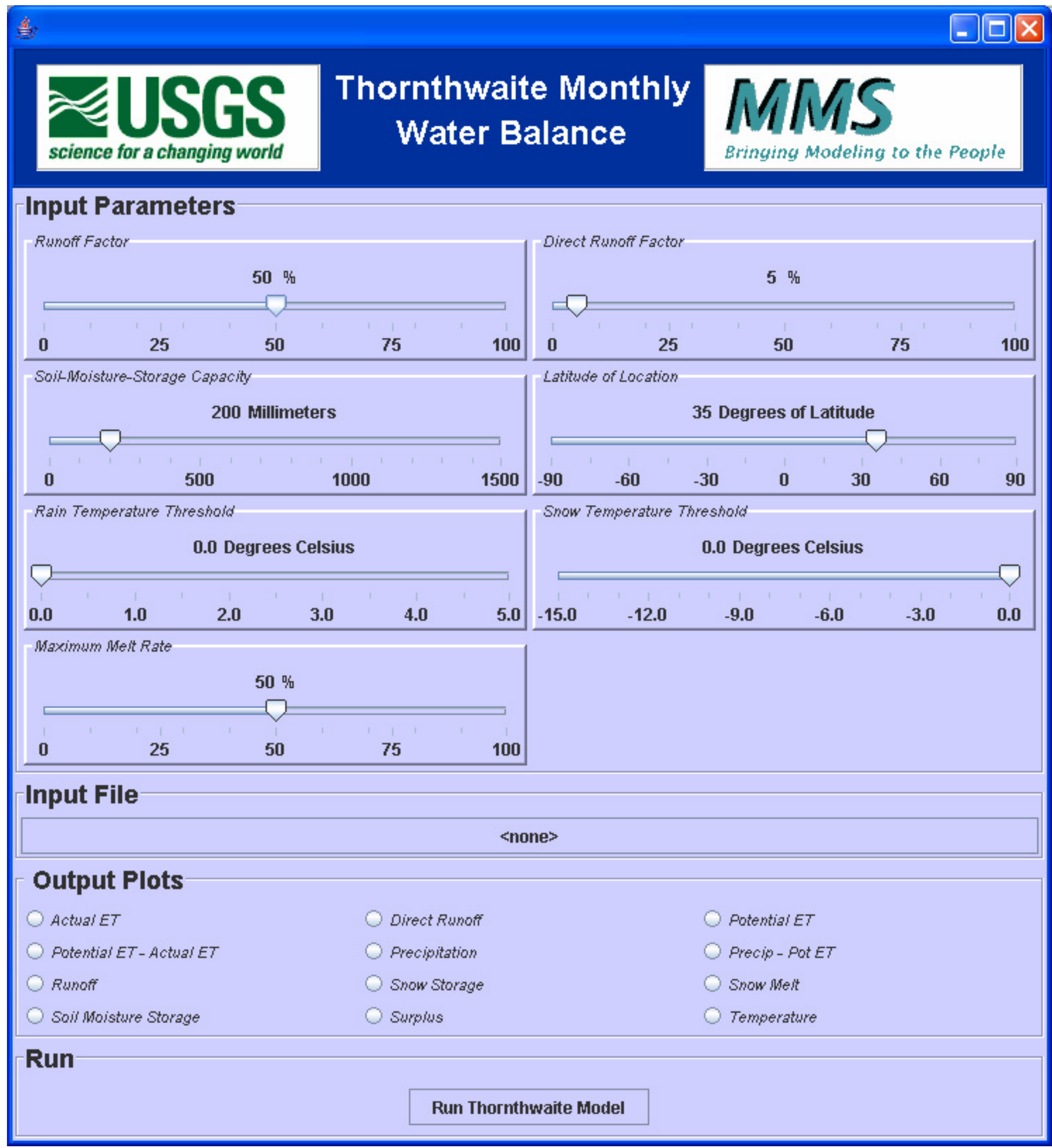

Figure 2. Screen image of the water-balance model graphical user interface. 


\begin{tabular}{|c|c|c|c|c|c|c|c|c|c|c|}
\hline \multicolumn{9}{|l|}{$\frac{1}{2}$} & \multicolumn{2}{|c|}{ - 0} \\
\hline Date & PET & P & P-PET & $\begin{array}{c}\text { Soil } \\
\text { Moisture }\end{array}$ & AET & PET-AET & $\begin{array}{c}\text { Snow } \\
\text { Storege }\end{array}$ & Surplus & Rototal & - \\
\hline 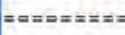 & $=2 x= \pm=$ & $x==x=-$ & $== \pm= \pm=E$ & 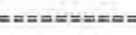 & $y=x==0$ & 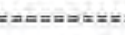 & 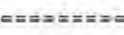 & 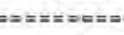 & 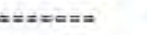 & \\
\hline $\operatorname{Jan}-1960$ & 18.0 & 44.1 & 23.9 & 173.9 & 18.0 & 0.0 & 0.0 & 0.0 & 14.9 & \\
\hline Feb-1960 & 18.2 & 62.9 & 41.6 & 200.0 & 18.2 & 0.0 & 0.0 & 15.5 & 17.2 & \\
\hline Mar-1960 & 28.5 & 32.8 & 2.7 & 200.0 & 28.5 & 0.0 & 0.0 & 2.7 & 10,0 & \\
\hline Apr-1960 & 70.1 & 48.5 & $-24,1$ & 175.9 & 70.1 & -0.0 & 0.0 & 0,0 & 6.6 & \\
\hline May-1960 & 98.0 & 150.6 & 45.1 & 200,0 & 98.0 & 0.0 & 0.0 & 21.0 & 20.1 & \\
\hline Jun-1960 & 147.5 & 74.7 & -76.6 & 123.4 & 147.5 & 0.0 & 0.0 & 0.0 & 10.0 & \\
\hline JuL-1960 & 156.7 & 151.8. & -12.5 & 115.7 & 151.9 & 4.8 & 0.0 & 0.0 & 10.7 & \\
\hline Aug-1960 & 142.1 & 88.1 & -58.4 & 81.9 & 117.5 & 24.6 & 0.0 & 0.0 & 6.0 & \\
\hline Sep-1960 & 96.2 & 60.6 & -38.6 & 66.1 & 73.4 & 22.8 & 0.0 & 0.0 & 3.8 & \\
\hline $0 c t-1960$ & 56.8 & 115.6 & 53.0 & 119.1 & 56.8 & 0.0 & 0.0 & 0.0 & 6.2 & \\
\hline Nov-1960 & 29.6 & 13.4 & -16.8 & 109.1 & 22.8 & 6.8 & 0.0 & 0.0 & 0.9 & \\
\hline Dec-1960 & 17.6 & 84.5 & 62.6 & 171.7 & 17.6 & 0.0 & 0.0 & 0.0 & 4.3 & \\
\hline $\operatorname{Jan}-1961$ & 17.5 & 10.0 & -8.0 & 164.9 & 16.4 & 1.1 & 0.0 & 0.0 & 0.6 & \\
\hline Feb-1961 & 24.0 & 43.5 & 17.4 & 182.3 & 24.0 & 0.0 & 0.0 & 0.0 & 2.2 & \\
\hline Mar-1961 & 41.9 & 90.0 & 43.6 & 200.0 & 41.9 & 0.0 & 0.0 & 25.9 & 17.4 & \\
\hline Apr-1961 & 60.7 & 27.0 & -35.1 & 154.9 & 60.7 & 0.0 & 0.0 & 0,0 & 7.8 & \\
\hline May-1961 & 100.5 & 123.5 & 16.9 & 181.8 & 100.5 & 0.0 & 0.0 & 0.0 & 9.4 & \\
\hline Jun-1961 & 131.7 & 111.6 & -25.6 & 158.5 & 129.3 & 2.3 & 0.0 & 0.0 & 7.2 & \\
\hline Ju1-1961 & 155.5 & 133.5 & -28.7 & 135.8 & 149.6 & 5.9 & 0.0 & 0.0 & 7.5 & \\
\hline Aug-1961 & 132.1 & 84.4 & -51.9 & 100.6 & 115.4 & 16.7 & 0.0 & 0.0 & 4.6 & \\
\hline Sep-1961 & 83.5 & 140.8 & 50.3 & 150.8 & 83.5 & 0.0 & 0.0 & 0.0 & 7,2 & \\
\hline Qct-1961 & 53.6 & 66.5 & 9.5 & 160.3 & 53.6 & 0.0 & 0.0 & 0.0 & 3.4 & 7 \\
\hline & & & & & & & & & & \\
\hline
\end{tabular}

Figure 3. Screen image of example output from the water-balance model.

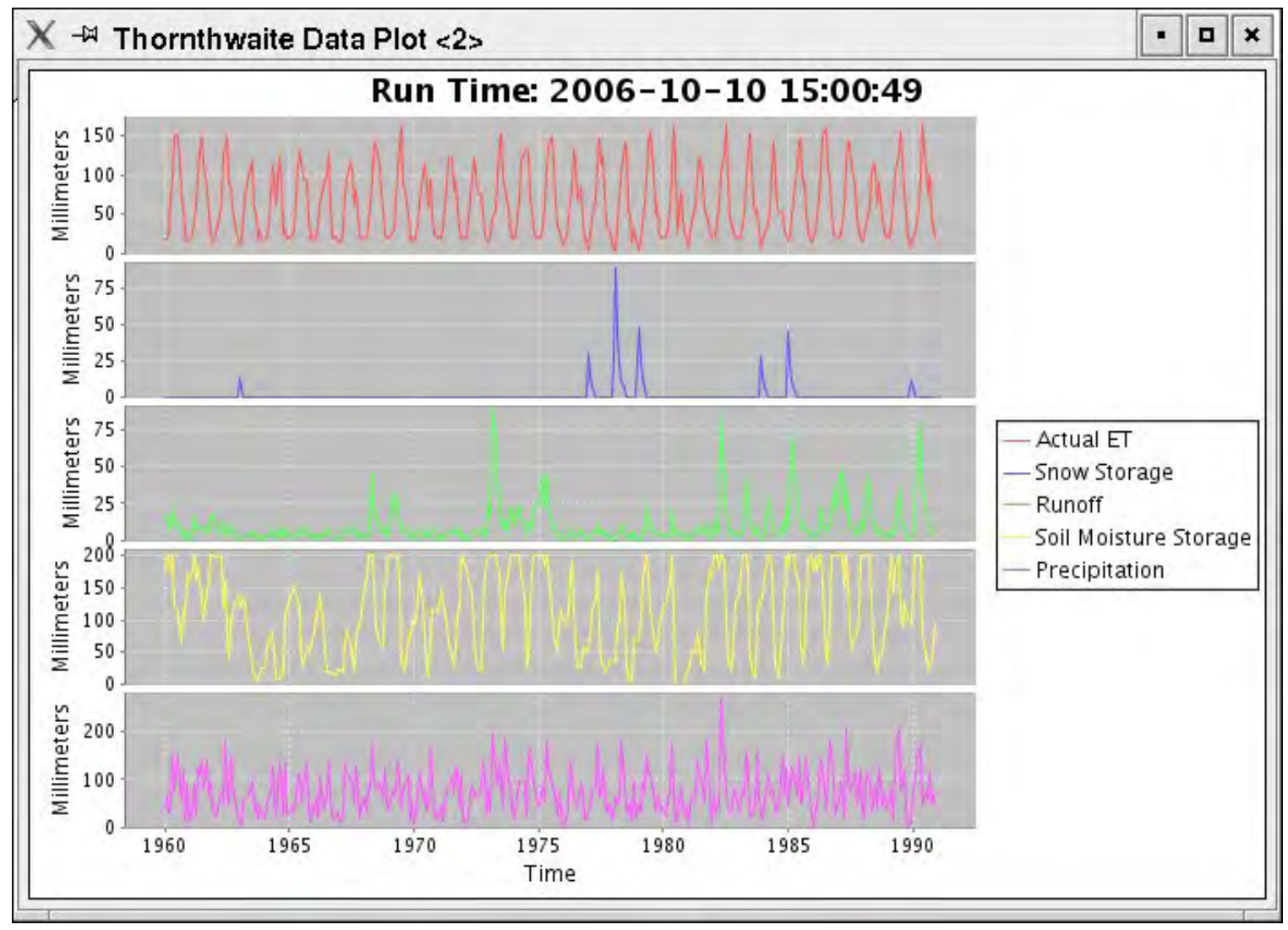

Figure 4. Screen image of example time series plotted by the water-balance model. 


\section{Summary}

Monthly water-balance models have been used to examine the various components of the hydrologic cycle (for example, precipitation, evapotranspiration, and runoff). This report presents a description of a monthly water-balance model, the Thornthwaite monthly water-balance program, which includes computations of monthly water-balance components for a specified location driven by a graphical user interface. The program can be downloaded from the internet and run on any computer platform. The program can be used for research, assessment purposes, and classroom instruction.

\section{References Cited}

Alley, W.M., 1984, On the treatment of evapotranspiration, soil moisture accounting, and aquifer recharge in monthly water balance models: Water Resources Research, v. 20, p. $1,137-1,149$.

Alley, W.M., 1985, Water balance models in one-month-ahead streamflow forecasting: Water Resources Research, v. 21, p. 597-606.

Hamon, W.R., 1961, Estimating potential evapotranspiration: Journal of the Hydraulics Division, Proceedings of the American Society of Civil Engineers, v. 87, p. 107-120.

Legates, D.R., and Mather, J.R., 1992, An evaluation of the average annual global water balance: Geographical Review, v. 82 , p. 253-267.

Legates, D.R., and McCabe, G.J., 2005, A re-evaluation of the average annual global water balance: Physical Geography, v. 26 , p. 467-479.

Mather, J.R., 1969, The average annual water balance of the world, in Symposium on Water Balance in North America, Series No. 7, Proceedings: Banff, Alberta, Canada, American Water Resources Association, p. 29-40.

Mather, J.R., 1978, The climatic water balance in environmental analysis: Lexington, Mass., D.C. Heath and Company, $239 \mathrm{p}$.
Mather, J.R., 1979, Use of the climatic water budget to estimate streamflow, in Mather, J.R., ed., Use of the climatic water budget in selected environmental water problems: Elmer, N.J., C.W. Thornthwaite Associates, Laboratory of Climatology, Publications in Climatology, v. 32, no. 1, p. 1-52.

McCabe, G.J., and Ayers, M.A., 1989, Hydrologic effects of climate change in the Delaware River basin: Water Resources Bulletin, v. 25, p. 1,231-1,242.

McCabe, G.J., and Wolock, D.M., 1992, Sensitivity of irrigation demand in a humid-temperate region to hypothetical climatic change: Water Resources Bulletin, v. 28, p. $535-543$

McCabe, G.J., and Wolock, D.M., 1999, Future snowpack conditions in the western United States derived from general circulation model climate simulations: Journal of the American Water Resources Association, v. 35, p. $1,473-1,484$.

Mintz, Y., and Serafini, Y.A., 1992, A global monthly climatology of soil moisture and water balance: Climate Dynamics, v. 8, p. 13-27.

Strzepek, K.M., and Yates, D.N., 1997, Climate change impacts on the hydrologic resources of Europe-A simplified continental scale analysis: Climatic Change, v. 36, p. 79-92.

Thornthwaite, C.W., 1948, An approach toward a rational classification of climate: Geographical Review, v. 38, p. 55-94.

Wolock, D.M., and McCabe, G.J., 1999, Effects of potential climatic change on annual runoff in the conterminous United States: Journal of the American Water Resources Association, v. 35, p. 1,341-1,350.

Yates, D.N., 1996, WatBal-An integrated water-balance model for climate impact assessment of river basin runoff: International Journal of Water Resources Development, v. 12, p. 121-140. 